\title{
Mutations of the Connexin 26 gene in families with non-syndromic hearing loss
}

\author{
WALID AL-ACHKAR, FATEN MOASSASS, BASSEL AL-HALABI and AYMAN AL-ABLOG
}

Department of Molecular Biology and Biotechnology, Division of Human Genetics, Atomic Energy Commission, Damascus, Syria

Received August 30, 2010; Accepted December 30, 2010

DOI: $10.3892 / \mathrm{mmr} .2011 .428$

\begin{abstract}
Autosomal recessive non-syndromic hearing impairment (ARNSHI) is caused by mutations in the gap junction gene GJB2 (Connexin 26; Cx26) in numerous human populations. The aim of this study was to determine the frequency of six GJB2 mutations in 50 Syrian families with congenital deafness and in 180 controls. PCR-RFLP was used to detect the 35delG, 167delT, M34T, W24X, W77R and E47X mutations, and direct sequencing was performed for the $35 \mathrm{delG}$ mutation. The data revealed a high prevalence of the $35 \mathrm{delG}$ mutation among deaf families. Homozygous $35 \mathrm{delG}$ was detected in fifteen of the Syrian families $(30 \%)$. A compound heterozygous genotype was observed in two families: one with the $35 \mathrm{delG} / 167 \mathrm{delT}$ mutation (2\%) and one with the $35 \mathrm{delG} / \mathrm{M} 34 \mathrm{~T}$ mutation (2\%). Nine families were heterozygous with no second identified mutation in Cx26: four with 35delG+/unknown (8\%), four with 167delT/unknown (8\%) and one with M34T/unknown (2\%). The W24X, W77R and E47X mutations were not detected in any of the study subjects. Three individuals with the heterozygous $35 \mathrm{delG}$ genotype (1.66\%) and five with the heterozygous 167delT genotype $(2.77 \%)$ were detected among the controls. No other mutations were found among the controls. These results have important implications for the diagnosis and counseling of families with Cx26 deafness.
\end{abstract}

\section{Introduction}

Hearing impairment is the most common sensory defect in humans and affects one in 1,000 children, with its prevalence increasing with age (1). More than $60 \%$ of cases of hearing impairment are due to genetic causes (2). Over 130 loci for non-syndromic deafness have been identified in humans $(3,4)$, and it is estimated that more than 100 genes are involved in

Correspondence to: Dr Walid Al-Achkar, Department of Molecular Biology and Biotechnology, Division of Human Genetics, Atomic Energy Commission of Syria, P.O. Box 6091, Damascus, Syria E-mail: ascientific@aec.org.sy

Key words: non-syndromic autosomal recessive deafness, connexin 26 , GJB2, polymerase chain reaction-restriction fragment length polymorphism hearing loss (5). Despite this heterogeneity, mutations in the GJB2 (Connexin 26; Cx26) gene are responsible for approximately $60 \%$ of prelingual non-syndromic recessive hearing loss, with a carrier frequency ranging between 2 and 5\% depending on the ethnic group (9).

DFNB1 (MIM 220290) was the first locus implicated in autosomal recessive deafness and prelingual hearing impairment, and was mapped to the $13 \mathrm{q} 12$ region (6). This locus additionally contains the genes GJB2 (MIM 121011) and GJB6 (MIM 604418), which encode the gap-junction proteins connexin 26 and connexin 30, respectively. Both genes are expressed in the cochlea in the inner ear (7), and are thought to be important for the passage of small metabolites, ion trafficking, homeostasis and the maintenance of endocochlear potential by providing a cell-cell pathway for the entry of potassium to the stria vascularis and back to the endolymph (8).

The GJB2 gene belongs to a family of transmembrane proteins with approximately twenty members in humans, and has a simple genomic structure comprising two exons. More than 90 different mutations of the GJB2 gene have been reported (10). Many are 'private' mutations observed in only one or a few pedigrees. However, commonly occurring alleles have been identified in several populations, including the $35 \mathrm{delG}$ allele, which is found in Caucasian (11), Mediterranean (12) and, less frequently, Egyptian (13), Turkish (14) and Jordanian (15) populations. Other frequently occurring mutations include 235delC among the Japanese and Koreans (16), 167delT among Ashkenazi Jews (17), R143W in an African village (18) and W24X in Indian populations (19).

The aim of this study was to determine the prevalence of six GJB2 gene mutations in Syrian patients with recessive non-syndromic congenital hearing impairment. To our knowledge, this is the first report on recessive autosomal deafness at a molecular level in Syrian families.

\section{Materials and methods}

Subjects and selection criteria. Fifty families were enrolled in this study. The patients were students attending the Educational Institute for the Hearing Impaired in Damascus. The age of the patients ranged from 2 to 18 years. Parents had normal hearing, with one or more affected children in each family. Written informed consent was obtained from all participants or from the parents of patients younger than 18 years. 
Table I. Parameters for PCR-RFLP used to detect point mutations.

\begin{tabular}{|c|c|c|c|c|c|c|}
\hline \multirow[t]{2}{*}{ Mutation } & \multirow[t]{2}{*}{$\begin{array}{l}\text { Primers sequences } \\
\qquad\left(5^{\prime}-3^{\prime}\right)\end{array}$} & \multirow[t]{2}{*}{$\begin{array}{c}\text { Amplified } \\
\text { fragment size }(b p)\end{array}$} & \multirow[t]{2}{*}{$\begin{array}{l}\text { Restriction } \\
\text { enzyme }\end{array}$} & \multicolumn{3}{|c|}{$\begin{array}{l}\text { Allele } \\
\text { size (bp) }\end{array}$} \\
\hline & & & & Normal & Homozygous & Heterozygous \\
\hline 35delG & $\begin{array}{l}\text { F: GGTGAGGTTGTGTAA GAGTTGG } \\
\text { R: CTGGTGGAGTGTTTGTTCCAC }\end{array}$ & 207 & BseLI & 207 & $181+26$ & $207+181+26$ \\
\hline 167delT & $\begin{array}{l}\text { F: GCTCACCGTCCTCTTCATTT } \\
\text { R: CTTCTTCTCATGTCTCCGGTA }\end{array}$ & 237 & PstI & $97+72+68$ & $165+72$ & $165+97+72+68$ \\
\hline W24X & $\begin{array}{l}\text { F: GAGGTATAATTGACAGATGAA } \\
\text { R: CAAACCGCCCAGAGTAGAAG }\end{array}$ & 114 & $\mathrm{XbaI}$ & 114 & $88+26$ & $114+88+26$ \\
\hline M34T & $\begin{array}{l}\text { F: CCTTTGCAGCCACAACGAT }{ }^{\mathrm{a}} \\
\text { R: CAAACCGCCCAGAGTAGAAG }\end{array}$ & 144 & BclI & $121+23$ & 14ww4 & $144+121+23$ \\
\hline $\mathrm{E} 47 \mathrm{X}$ & $\begin{array}{l}\text { F: GCAAAGGAGGTGTGGGGAGAC } \\
\text { R: GGATGTGGGAGATGGGGAAGTA }\end{array}$ & 106 & BfaI & 106 & $85+21$ & $106+85+21$ \\
\hline W77R & $\begin{array}{l}\text { F: CCATCTCCCACATCCGGCTC } \\
\text { R: GCCTTCGATGCGGACCTTCT }\end{array}$ & 182 & MspI & $100+82$ & 182 & $182+100+82$ \\
\hline
\end{tabular}

Underlined nucleotides correspond to cDNA nucleotide positions 233-254, with a mutation at nucleotide position 236. ${ }^{\text {aB }}$ ases modified to be compatible with the selected enzyme.

A detailed medical history and pedigree structure were obtained through personal interviews with the affected individuals or their unaffected relatives. The medical history included obstetric and perinatal data (whether the mother experienced toxoplasmosis, diabetes or other infections, or was exposed to medication, drugs or any vaccinations during pregnancy) and information on area of origin, consanguinity, onset, course and duration of hearing loss, symmetry of the hearing impairment, history of chronic diseases such as middle ear infections, medical treatment, noise damage, trauma, meningitis, ototoxic agents, head trauma, fever and ear operations.

Careful clinical examination was conducted to exclude patients with syndromic deafness and other associated anomalies. Only patients with a bilateral hearing disorder and congenital onset were included in the study.

Pure-tone audiometry and speech audiometry were performed to determine the degree of hearing in both ears. Auditory brain stem response was evaluated to confirm the hearing threshold, and otoacoustic emission was used to exclude patients with central auditory system injury.

\section{Genetic analysis.}

DNA extraction. Anticoagulated venous blood (5 ml) was obtained from the patients and controls. DNA was extracted using the QIAamp DNA Blood Mini kit (Qiagen, Germany) according to the manufacturer's instructions. Purified DNA was run on a $0.8 \%$ agarose gel. The quality and quantity of the DNA was determined spectrophotometrically.

Polymerase chain reaction. Primer sets easily differentiated by restriction enzyme and direct sequencing were designed to amplify the fragment containing the mutation (Table I) (20). Polymerase chain reaction (PCR) was performed in a final volume of $25 \mu \mathrm{l}$ containing $30 \mathrm{ng}$ of genomic DNA, $12.5 \mu \mathrm{l}$ AmpliTaq Gold PCR Master Mix (Applied Biosystems, USA), $1 \mu \mathrm{l}(10 \mathrm{pmol})$ of each primer and $9.5 \mu \mathrm{l}$ of distilled water. Amplification was carried out in a thermocycler (TC-512; Techne, UK). The amplification procedure for the $35 \mathrm{delG}$, 167delT, M34T, E47X and W77R mutations was: initial denaturation at $94^{\circ} \mathrm{C}$ for $5 \mathrm{~min}$, followed by 40 cycles at $94^{\circ} \mathrm{C}$ for 1 $\min , 60^{\circ} \mathrm{C}$ for $1 \mathrm{~min}$ and $72^{\circ} \mathrm{C}$ for $1 \mathrm{~min}$, and a final extension at $72^{\circ} \mathrm{C}$ for $5 \mathrm{~min}$. For the $\mathrm{W} 24 \mathrm{X}$ mutation, the same amplification protocol was followed at one exception: the annealing temperature was $57^{\circ} \mathrm{C}$ for $1 \mathrm{~min}$. The amplification products were loaded on a $2.5 \%$ agarose gel with $1 \mathrm{X}$ TAE running buffer and visualized using ethidium bromide fluorescence under ultraviolet light. The band size was determined using a 100-bp DNA ladder (Fermentas, Lithuania).

Restriction fragment length polymorphism technique. Mutations were detected using PCR-restriction fragment length polymorphism (RFLP) (21). PCR products were digested using the restriction enzymes (Fermentas, Lithuania) listed in Table I. The total reaction volume contained $15 \mu \mathrm{l}$ of the PCR product, $2 \mu 1$ of $10 \mathrm{X}$ NB buffer, $1 \mu 1$ of a specific enzyme $(10 \mathrm{U} / \mu \mathrm{l})$ and $2 \mu \mathrm{l}$ of nuclease-free water. The reaction mixture was incubated according to each restriction enzyme. Digested PCR products $(15 \mu 1)$ were added to $3 \mu 16 \mathrm{X}$ loading dye and loaded on a 5\% 3:1 agarose gel (Eurobio, France) and run at $100 \mathrm{~V}$ for $2 \mathrm{~h}$. The product size was determined using a 25-bp DNA ladder (Pan-Biotech, Germany).

Sequencing. Direct DNA sequencing for the $35 \mathrm{delG}$ mutation was carried out in both directions using forward and reverse primers (Table I) on an ABI PRISM 310 Genetic Analyzer (Applied Biosystems, Foster City, CA, USA). The cycle-sequencing reaction was performed in a $10-\mu 1$ volume containing $1 \mu \mathrm{l}$ of the terminator ready reaction, 5 pmol of 
Table II. Frequency of mutations in exon 2 of Connexin 26 in families with non-syndromic hearing loss.

\begin{tabular}{|c|c|c|c|}
\hline \multirow[t]{2}{*}{ Mutation } & \multirow[t]{2}{*}{ Genotype } & \multicolumn{2}{|c|}{ Frequency } \\
\hline & & $\begin{array}{c}\text { Families }(\mathrm{n}=50) \\
\text { no. }(\%)\end{array}$ & $\begin{array}{c}\text { Controls }(\mathrm{n}=180) \\
\text { no. }(\%)\end{array}$ \\
\hline \multirow[t]{4}{*}{ 35delG } & 35delG/35delG & $15(30)$ & - \\
\hline & 35delG/167delT & $1 \quad(2)$ & - \\
\hline & 35delG/unknown & $4 \quad(8)$ & $3(1.66)$ \\
\hline & 35delG/M34T & 1 (2) & - \\
\hline $167 \mathrm{delT}$ & 167delT/unknown & $4 \quad(8)$ & $5(2.77)$ \\
\hline M34T & M34T/unknown & $1 \quad(2)$ & - \\
\hline W24X & - & - & - \\
\hline $\mathrm{E} 47 \mathrm{X}$ & - & - & - \\
\hline W77R & - & - & - \\
\hline
\end{tabular}

A

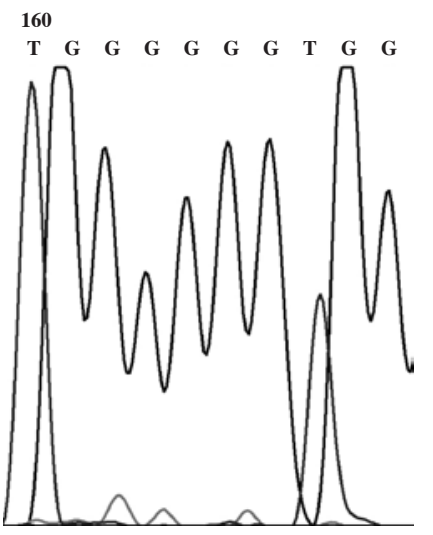

B

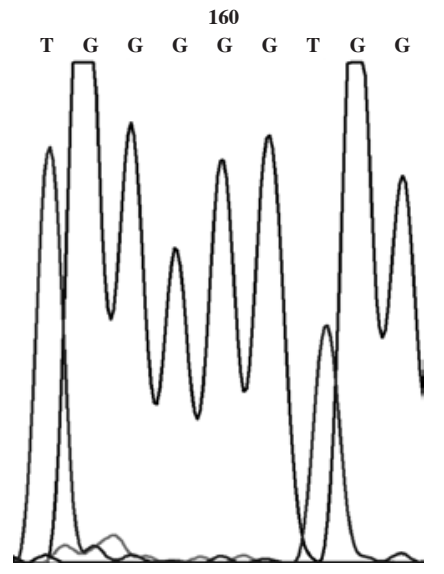

Figure 1: DNA sequencing of the GJB2 coding exon for the 35delG mutation. (A) Wild type DNA; (B) mutant DNA.

either the forward or reverse primer and $10 \mathrm{ng}$ of purified PCR product (ExoSAP-IT kit; Amersham BioSciences, Piscataway, $\mathrm{NJ})$. The thermal cycle protocol was $95^{\circ} \mathrm{C}$ for 4 min followed by 30 cycles at $96^{\circ} \mathrm{C}$ for $10 \mathrm{sec}, 50^{\circ} \mathrm{C}$ for $5 \mathrm{sec}$ and $60^{\circ} \mathrm{C}$ for 4 min (ABI GeneAmp PCR System 9700, Applied Biosystems). Centri-Sep columns (Princeton Separations, Adelphia, NJ, USA) were used for the effective and reliable removal of
A

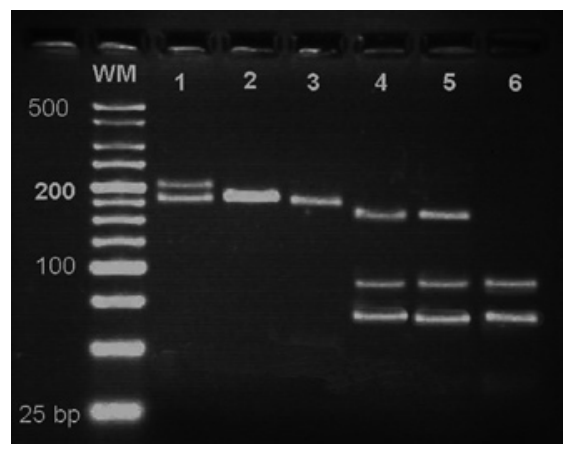

B

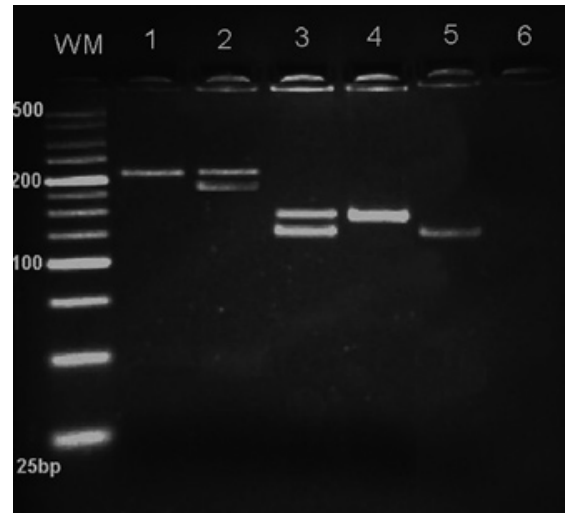

Figure 2. PCR-RFLP for mutations in exon 2 of Cx26. PCR products were digested in the restriction enzymes (A) BselI and PstI for the $35 \mathrm{delG}$ and 167delT mutations, respectively, or (B) BselI and BclI for the 35delG and M34T mutations, respectively. (A) Lane WM, 25-bp DNA ladder; lanes 1-4, deaf patient with compound heterozygous 35delG/167delT; lanes 2-3, positive control and deaf patient with homozygous $35 \mathrm{delG}$; lane 5: positive control with heterozygous $167 \mathrm{delT}$; lane 6 , normal control for $167 \mathrm{delT}$. (B) Lane WM, 25-bp DNA ladder; lane 1, normal control with 35delG; lanes 2-3, deaf patient with compound heterozygous 35delG/M34T; lane 4, PCR product for M34T mutation; lane 5, normal control for M34T; lane 6, PCR blank.

excess dye terminators (DyeEx2.0, Qiagen) from completed DNA sequencing reactions. Data were compared and aligned with different sequences using the NCBI BLAST Assembled Genomes tool (http://blast.ncbi.nlm.nih.gov/Blast.cgi).

\section{Results}

This study investigated gene mutations associated with prelingual non-syndromic hearing loss in 50 Syrian families and 180 controls. Among the deaf patients, 38 were male and 52 female. All had profound hearing loss. Positive parental consanguinity was present in $50 \%$ of the studied families. Screening for six mutations in Cx26 was performed in two steps. First, the $35 \mathrm{delG}$ and $167 \mathrm{delT}$ mutations were screened in the deaf patients using restriction enzyme analysis of the PCR products. Second, when no $35 \mathrm{delG}$ and 167delT mutations were detected in deaf patients nor the heterozygous form of these two mutations, screening was conducted for the W24X, M34T, E47X and W77R mutations. Data for the patients and controls are presented in Table II. 35delG was the most common mutant allele in Cx26 in the Syrian families. Homozygous $35 \mathrm{delG}$ was detected in fifteen families (30\%), as confirmed by direct sequencing (Fig. 1). A compound heterozygous genotype was observed in two families: one with the 35delG/167delT mutation (2\%) (Fig. 2A) and one with 
the 35delG/M34T mutation (2\%) (Fig. 2B). Nine families were heterozygous with no second identified mutation in Cx26: four with 35delG+/unknown (8\%), four with $167 \mathrm{delT} /$ unknown (8\%) and one with M34T/unknown (2\%). The W24X, W77R and E47X mutations were not detected in any of the study subjects. Three individuals with the heterozygous $35 \mathrm{delG}$ genotype $(1.66 \%)$ and five with the heterozygous 167delT genotype (2.77\%) were detected among the controls. No other mutations were found among the controls.

\section{Discussion}

GJB2, the gene encoding the gap-junction protein connexin 26 , has been revealed to underlie distinct forms of hearing impairment, in particular autosomal recessive non-syndromic hearing impairment (ARNSHI). Mutations in GJB2 are the most common cause of moderate-to-profound congenital inherited hearing impairment in numerous populations (22). Among the genotypic variants identified was $35 \mathrm{delG}$, which causes a frameshift mutation generating a premature stop codon and is reported to be more prevalent among Caucasians $(11,23)$. In populations of European origin, the $35 \mathrm{delG}$ mutation accounts for up to $80 \%$ of GJB2 allelic mutations, and is most frequent in southern European countries around the Mediterranean (24-25). In this study, we investigated the association between six Cx 26 mutations and non-syndromic recessive hearing loss in Syrian families. The basis of the selection of these mutations was dependant on their reported presence in the Middle East and neighboring countries $(12,14,28)$.

Our results revealed the frequency of the $35 \mathrm{delG}$ mutation among deaf patients. 35delG was homozygous in 15/50 families (30\%). This result was higher than that of previous studies in Jordanian (13.6\%) (26), Palestinian (14\%) (27), Egyptian (16\%) (13) and Iranian (5.66\%) (28) populations, and lower than that in Lebanese (94\%) (29) and European (60-80\%) (30) populations. The high level of consanguinity in many Syrian families (50\%) explained the high frequency of 35delG homozygosis (30\%). The carrier frequency of the $35 \mathrm{delG}$ mutation in the controls was $1.66 \%$. This frequency was higher than that in the Jordanian population (1.1\%) but lower than that in carriers reported in many other countries. The highest carrier frequency of $35 \mathrm{delG}$ found to date was in Italians (3.2\%) (9).

The second most frequently occurring variant found in this study after $35 \mathrm{delG}$ was the $167 \mathrm{delT}$ mutation, which has also been found to be a cause of ARNSHI (31). This mutation was predominantly identified in Ashkenazi Jews and was attributed to a founder effect based on haplotype analysis (31). Our genotyping results revealed the presence of the compound heterozygous form of $167 \mathrm{delT}$ and $35 \mathrm{delG}$ (35delG/167delT) in one family (2\%) and a 167 delT/unknown mutation in four families (8\%). The carrier rate of this mutation in a control group of Ashkenazi Jews was $4.03 \%$ (31). In our study, the carrier frequency was $2.77 \%$ among the Syrian controls.

The M34T variant was first described as an autosomal dominant mutation (32). Other reports have defined the M34T allele as an autosomal recessive mutation in the presence of other GJB2 mutations or homozygosity $(33,34)$. If M34T is indeed a polymorphism, patients with the $35 \mathrm{delG} / \mathrm{M} 34 \mathrm{~T}$ genotype are carriers of only one GJB2 mutation (35delG) and their hearing impairment should be caused by different unidentified mutations in GJB2 or other genes. M34T is reported to have a high frequency in the general Caucasian population, comparable to that of $35 \mathrm{delG}$ (35). In the present study, only one family (2\%) had a $35 \mathrm{delG} / \mathrm{M} 34 \mathrm{~T}$ genotype, and another had a M34T/unknown genotype.

W24X is another commonly found allele, and has been associated with ARNSHI in the north and south of India $(36,37)$. The incorporation of a stop codon in this mutation at codon 24 of $\mathrm{Cx} 26$ causes the formation of a protein that is just $1 / 10$ the length of the wild-type protein (32). This mutation was not found in our study, indicating a relatively low frequency of this mutant allele in Syria.

The W77R missense allele encodes a GJB2 polypeptide with residual gap-junction assembly and intercellular coupling activity similar to that of M34T (38). W77R was initially detected in a large pedigree co-segregating recessive deafness DFNB1 with the $35 \mathrm{delG}$ and W77R alleles of GJB2 (39). Affected individuals were homozygous for $35 \mathrm{delG}$ and W77R, and compound heterozygous for W77R/35delG, indicating that W77R is indeed a mutant allele of GJB2 (40). The W77R and E47X mutations were reported by Moreno et al at a frequency of $3.7 \%$ and $5.1 \%$ in Spanish and Cuban patients, respectively (41). In the present study, the W77R and E47X mutations were not detected in any of the deaf families, suggesting the absence or low incidence of this mutation in Syria.

The results of the present study revealed the need to focus on the screening of newborns for various mutations in Cx26 for early intervention and language development, taking advantage of residual hearing. Screening for the $35 \mathrm{delG}$ mutation among others found in this study may be used to identify carriers among the general population, and thus aid in the counseling of families with Cx26 deafness.

\section{Acknowledgements}

The authors thank Dr I. Othman, the Director General of the Atomic Energy Commission of SYRIA (AECS) and Dr N. Mirali, the Head of Molecular Biology and Biotechnology Department for their support, and all the families, students and personnel of the Educational Institute for the Hearing Impaired in Damascus, Syria. This study was supported by the AECS.

\section{References}

1. Rabionet R, Gasparini P and Estivill X: Molecular genetics of hearing impairment due to mutations in gap junction genes encoding beta connexins. Hum Mutat 16: 190-202, 2000.

2. Petit C, Levilliers J and Hardelin JP: Molecular genetics of hearing loss. Annu Rev Genet 35: 589-646, 2001.

3. Kenneson A, Van Naarden Braun K and Boyle C: GJB2 (connexin 26) variants and nonsyndromic sensorineural hearing loss: a HuGE review. Genet Med 4: 258-274, 2002.

4. Tranebjaerg L: Genetics of congenital hearing impairment: a clinical approach. Int J Audiol 47: 535-545, 2008.

5. Ballana E, Ventayol M, Rabionet R, Gasparini P and Estivill X: Connexins and deafness. The Connexins and Deafness Homepage: http://davinci.crg.es/deafness. Accessed 2010.

6. Guilford P, Ben Arab S, Blanchard S, Levilliers J, Weissenbach J, Belkahia A and Petit C: A non-syndromic form of neurosensory, recessive deafness maps to the pericentromeric region of chromosome 13q. Nat Genet 6: 24-28, 1994. 
7. Forge A, Becker D, Casalotti S, Edwards J, Marziano N and Nevill G: Gap junctions in the inner ear: comparison of distribution patterns in different vertebrates and assessment of connexin composition in mammals. J Comp Neurol 467: 207-231, 2003.

8. Kikuchi T, Adams JC, Miyabe Y, So E and Kobayashi T: Potassium ion recycling pathway via gap junction systems in the mammalian cochlea and its interruption in hereditary nonsyndromic deafness. Med Electron Microsc 33: 51-56, 2000.

9. Gasparini P, Rabionet R, Barbujani G, et al: High carrier frequency of the $35 \mathrm{delG}$ deafness mutation in European populations. Genetic Analysis Consortium of GJB235delG. Eur J Hum Genet 8: 19-23, 2000.

10. Marlin S, Feldmann D, Blons H and Loundon N: GJB2 and GJB6 mutations. Arch Otolaryngol Head Neck Surg 131: 481-486, 2005.

11. Nance WE: The genetics of deafness. Ment Retard Dev Disabil Res Rev 9: 109-119, 2003.

12. Estivill X, Fortina P, Surrey S, et al: Connexin-26 mutations in sporadic and inherited sensorineural deafness. Lancet 351 394-398, 1998

13. Mustafa MW: Prevalence of the connexin 26 mutation $35 \mathrm{delG}$ in non-syndromic hearing loss in Egypt. Internet J Otorhinolar 3 : http://www.ispub.com/ostia/index.php?xmlFilePath=journals/ ijorl/vol3n1/connexin.xml, 2004

14. Kalay E, Caylan RK, Kremer H, Brouwer AP and Karaguzel A GJB2 mutations in Turkish patients with ARNSHL: prevalence and two novel mutations. Hear Res 203: 88-93, 2005.

15. Mahasneh AA: Prevalence of connexin 26 mutations in nonsyndromic recessive deafness in the Jordanian population. Int J Hum Genet 6: 119-124, 2006

16. Abe S, Usami S, Shinkawa H, Kelley PM and Kimberling WJ Prevalent connexin 26 gene (GJB2) mutations in Japanese. J Med Genet 37: 41-43, 2000.

17. Sobe T, Ehrlich P, Berry A, Korostichevsky M, Vreugede S, Avraham KB, Bonne-Tamir B and Shohat M: High frequency of the deafness-associated 167delT mutation in the connexin 26 (GJB2) gene in Israeli Ashkenazim. Am J Med Genet 86 499-450, 1999

18. Brobby GW, Muller-Myhsok B and Horstmann RD: Connexin 26 R143W mutation associated with recessive nonsyndromic sensorineural deafness in Africa. N Engl J Med 338: 548-549, 1998.

19. Ghosh M, Vijaya R and Kabra M: Genetics of deafness in India. Indian J Pediatr 71: 531-533, 2004.

20. Perea Y, Mato J, Amores I and Ferreira R: Study of six mutations in the gjb2 gene in Cuban patients with nonsyndromic sensorineural deafness. Biotecnol Apl 24: 241-245, 2007.

21. Sambrook J, Fritsch EF and Maniatis T (eds): Molecular Cloning: A Laboratory Manual. Vol 1. 2nd edition. Ford N, Nolan C Ferguson M (eds). Cold Spring Harbor Laboratory Press, Cold Spring Harbor, New York, pp5-6, 1989.

22. Scott DA, Kraft ML, Carmi R, et al: Identification of mutation in the Connexin 26 gene that cause autosomal recessive nonsyndromic hearingloss. Hum Mutat 11: 387-394, 1998.

23. Zelante L, Gasparini P, Estivill X, et al: Connexin26 mutations associated with the most common form of non-syndromic neurosensory autosomal recessive deafness (DFNB1) in Mediterraneans. Hum Mol Genet 6: 1605-1609, 1997.

24. Cryns K, Orzan E, Murgia A, et al: A genotype-phenotype correlation for GJB2 (connexin 26) deafness. J Med Genet 41 : 147-154, 2004.

25. Janecke AR, Hirst-Stadlmann A, Günther B, Utermann B, Müller T, Löffler J, Utermann $G$ and Nekahm-Heis $D$ : Progressive hearing loss, and recurrent sudden sensorineural hearing loss associated with GJB2 mutations - phenotypic spectrum and frequencies of GJB2 mutations in Austria. Hum Genet 111: 145-153, 2002.
26. Medlej-Hashim M, Mustapha M, Chouery E, et al: Non-syndromic recessive deafness in Jordan: mapping of a new locus to chromosome 9q34.3 and prevalence of DFNB1 mutations. Eur J Hum Genet 10: 391-394, 2002.

27. Shahin H, Walsh T, Sobe T, Lynch E, King MC, Avraham KB, and Kanaan M: Genetics of congenital deafness in the Palestinian population: multiple connexin 26 alleles with shared origins in the Middle East. Hum Genet 110: 284-289, 2002.

28. Mustaapha BM, Salem N, Delague V, et al: Autosomal recessive non-syndromic hearing loss in the Lebanese population: prevalence of the 30delG mutation and report of two novel mutations in the connexin 26 (GJB2) gene. J Med Genet 38: E36, 2001.

29. Hashemzadeh Chaleshtori M, Hoghooghi Rad L, Dolati M, et al: Frequencies of mutations in the connexin 26 gene (GJB2) in two populations of Iran (Tehran and Tabriz). Iranian J Publ Health 34: 1-7, 2005.

30. Wilcox SA, Osborn AH and Dahl HH: Simple PCR test to detect the common 35 delG mutation in the connexin 26 gene. Mol Diagn 5: 75-78, 2000.

31. Lerer I, Sagi M, Malamud E, Levi H, Rothschild AR and Abeliovich D: Contribution of connexin 26 mutations to nonsyndromic deafness in Ashkenazi patients and the variable phenotypic effect of the mutation 167delT. Am J Med Genet 95: 53-56, 2000.

32. Kelsell DP, Dunlop J, Stevens HP, Lench NJ, Liang JN, Parry G, Mueller RF and Leigh IM: Connexin 26 mutations in hereditary non-syndromic sensorineural deafness. Nature 387: 80-83, 1997.

33. Wilcox SA, Saunders K, Osborn AH, et al: High frequency hearing loss correlated with mutations in the GJB2 gene. Hum Genet 106: 399-405, 2000.

34. Kenneson A, van Naarden Braun K and Boyle C: GJB2 (connexin 26) variants and nonsyndromic sensorineural hearing loss: a HuGE review. Genet Med 4: 258-274, 2002.

35. Roux AF, Pallares-Ruiz N, Vielle A, et al: Molecular epidemiology of DFNB1 deafness in France. BMC Med Genet 5: 5, 2004.

36. Maheswari M, Vijaya R, Ghosh M, Shastri S, Kabra M and Menon PSN: Screening of families with autosomal recessive nonsyndromic hearing impairment (ARNSHI) for mutations in GJB2 gene. Indian Scenario. Am J Med Genet 120: 180-184, 2003.

37. Ramshankar M, Girirajan S, Dagan O, Ravi Shankar HM, Jalvi R, Rangasayee R, Avraham KB and Anand A: Contribution of connexin26 (GJB2) mutations and founder effect to nonsyndromic hearing loss in India. J Med Genet 40: E68, 2003.

38. Martin PE, Coleman SL, Casalotti SO, Forge A and Evans WH: Properties of connexin26 gap junctional proteins derived from mutations associated with non-syndromal hereditary deafness. Hum Mol Genet 8: 2369-2376, 1999.

39. Carrasquillo MM, Zlotogora J, Barges S, and Chakravarti A Two different connexin 26 mutations in an inbred kindred segregating non-syndromic recessive deafness: implications for genetic studies in isolated populations. Hum Mol Genet 6: 2163-2172, 1997.

40. Griffith AJ, Chowdhry AA, Kurima K, Hood LJ, Keats B, Berlin CI, Morell RJ and Friedman TB: Autosomal recessive nonsyndromic neurosensory deafness at DFNB1 not associated with the compound-heterozygous GJB2 (connexin 26) genotype M34T/167delT. Am J Hum Genet 67: 745-49, 2000

41. Moreno F, San Millán JL, Hernández C and Del Castillo I: Contribuciones Científicas al Conocimiento de las Bases Moleculares de Cuatro Enfermedades Genéticas. 1st edition. Real Patronato sobre Discapacidad, Madrid, 2003. 